\title{
東日本大震災における石巻市内での避難行動 一移動パターン・移動距離からの分析一
}

\author{
柳原 純夫 ${ }^{1}$ ・村上 ひとみ ${ }^{2}$ \\ ${ }^{1}$ 正会員＼cjkstart奥村組東日本支社土木技術部（干108-8381 東京都港区芝 5-6-1） \\ E-mail:sumio. yanagihara@okumuragumi.jp \\ 2 正会員 山口大学准教授 理工学研究科環境共生系専攻（干755-8611 山口県宇部市常盤台 2-16-1) \\ E-mail: hitomim@yamaguchi-u. ac.jp
}

\begin{abstract}
石巻市内の仮設住宅を対象に実施されたポスティングアンケート結果から本庁地区についての各避難者 の避難手段と津波が到達するまでの移動距離を抽出し整理した。そのデータを元に避難経路, 移動パター ンについて検討した．その結果次のことが明らかとなった１）自動車避難が半数を占める 2) 徒歩避難, 自動車避難ともに近隣の避難場所に移動したケースが多い 3 ) 自動車避難の $1 / 4$ は一度自宅に戻っている 4) 自動車避難の $2 / 5$ は渋滞に巻き込まれている 5 ) 自動車避難で一度自宅に戻った場合, 平均的な避難可能 時間は約17分であった。
\end{abstract}

Key Words : the great east Japan earthquake disaster, tsunami, Ishinomaki, evacuation

\section{1.はじめに}

東日本大震災津波避難合同調査団（山田町・石巻市担 当チーム） ${ }^{1)}$ にて実施された仮設住居入居者 355 名（石 巻市）を対象としたヒアリング調查結果 ${ }^{2)}$ によると地震 後の住民の避難行動には次の傾向があった.

(1) 近隣の学校や日和山, 牧山などの高台に避難するケ 一スが多かった。

(2) 自動車を用いた避難ケースが多く, 道路の主要交差 点，避難所の出入り口を中心に渋滞が発生した.

(3) 徒歩避難では近傍 ( $1 \mathrm{~km}$ 以内) の避難場所に移動する ケースが多かった.

(4) 地震発生が平日の昼間であり職場, 外出先などから 数 $\mathrm{km}$ 離れた自宅を経由して避難するケースも多く, 自宅に戻った直後に津波に吞まれ流されたケース も散見された。

国土交通省は津波の浸水被害を受けた 6 県（青森・岩 手・宮城・福島・茨城・千葉）について，聞き取り調査

（ヒアリング方式）により移動目的，避難開始時間，避 難回数, 移動手段, 避難に要した時間, 避難路, 等につ いて実態を調査し津波避難を想定した避難路や避難施設 の配置，避難誘導等についてとりまとめている ${ }^{3)}$.

ここでは石巻市を対象として実施したポスティングア ンケート結果（797 票回収）から，石巻市本庁地区に絞
り，平均移動距離，移動手段，地域内移動パターンの詳 細，外出先から自宅を経由する避難，渋滞との関連性等 についてとりまとめた.

データとりまとめにあたっては「仮設住宅居住者の元 住所」や「避難場所」(学校, 高台) などから確実に位置 を特定できるデータが比較的多い移動距離と移動手段を 基本とした ${ }^{4)}$.

\section{2. 避難手段別の移動距離の抽出}

\section{（1）アンケート回答からの避難距離の抽出方法}

ポスティングアンケートは東日本大震災津波避難合同 調查団（山田町・石巻市担当チーム）で実施したもので ある ${ }^{1)}$. 2011 年 12 月に石巻市でアンケート調查票を仮 設住宅のポストに配布し返信用封筒で返送していただい た. 3, 300 戸に配布し 797 票 $(24 \%)$ が回収された.この うち今回検討対象とした石巻市本庁地区における避難行 動に関するものは 689 票であった.

アンケートは 31 項目の質問で構成されその殆どが選 択形式であるが，本文で扱う「移動距離」はアンケート 中の「避難を始めてから最初の避難先に着くまで（また は津波に巻き込まれるまで）の経路とおよその所要時間 をお書きください」との問いに対する図-1 の様式への文 書回答を元に抽出した. 


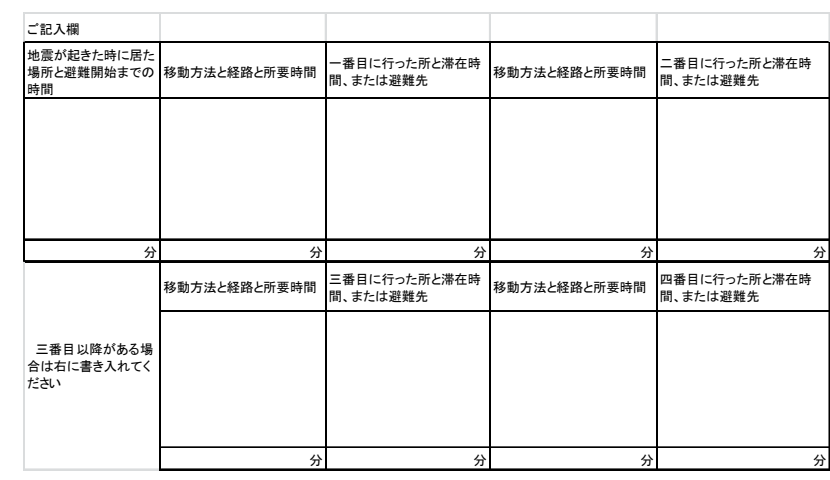

図-1アンケート回答フォーマット

「移動距離」は津波が遡上してくるまでに移動し得た 距離という観点から次のように定義した。

（1) 安全に避難できたケースでは，職場，自宅，避難所 など各人が出発，経由，到達した地点をアンケート の記述をもとに地図上にプロットし各拠点間の直 線距離を計測しこれらを合計する.（図-2）

(2) 移動途中に遡上してきた津波に追いつかれたり巻 き込まれたりしたケースは, その地点までの距離を 計測する.

（3)移動手段としては「徒歩で避難」，「自動車で避難」,

「自転車で避難」に分類した。自動車で避難した後 に歩いて避難するなど移動手段が複数の場合は, 移 動距離の長い移動手段に分類した，なお，「歩いて 避難」とするケースには，地震後数時間経過してか ら歩いて避難所に行ったものや同一建物の上階に 歩いて避難したケースは含まない.

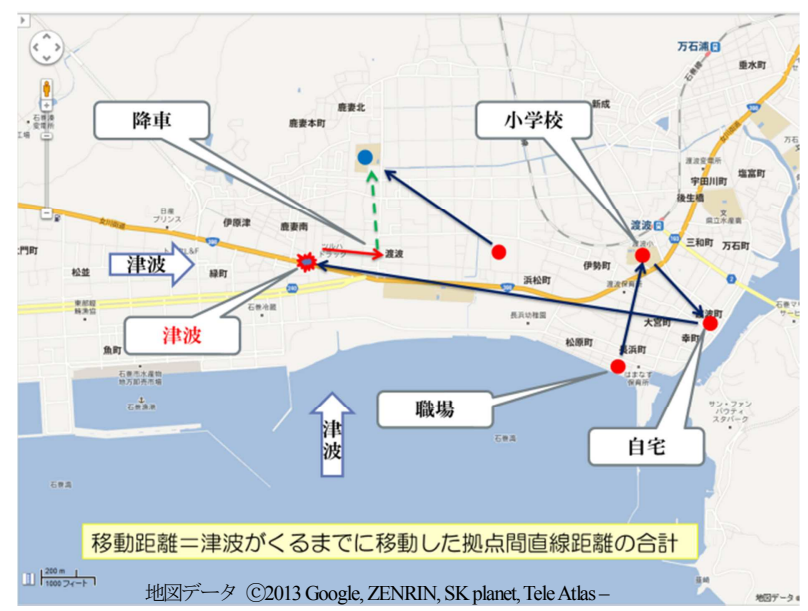

図-2 移動経路の地図上へのプロット

\section{（2）避難手段別の移動距離}

抽出した集計結果を表-1に示寸. 全回答 797 件のうち, 検討対象範囲外である牡鹿半島等リアス部での避難ケー スが 108 件，文書回答からは移動距離が読み取れないも のが 104 件あり避難パターンが明確となったものは 585 件である。そのうち自動車による避難が 303 件と約 52\%
を占め, 自宅にとどまる (約 23\%)，徒歩避難（約 23\%） それぞれのケースの 2 倍以上になっている.

2010 年国勢調查 ${ }^{5}$ によよれば, 図-3 に示すように石巻市 における 15 歳以上の常住者の通勤·通学交通手段は自家 用車が $72 \%$ と多数を占め，鉄道・電車，バスなど公共交 通は少ない．図中に併記している全国集計値と比較して もその傾向は顕著である.

平常時の通勤・通学で自動車の利用割合が高く, 地震 発生時刻が平日昼間であったことが地震避難時において も自動車の依存率を高める基本的な要因になっていると 推察される.

表-1 集計件数

\begin{tabular}{|c|c|c|}
\hline & 避難パターン & 件数 \\
\hline \multirow{5}{*}{$\begin{array}{c}\text { 石巻市本庁地区で距 } \\
\text { 離の特定できたケー } \\
ス\end{array}$} & 自宅にとどまる & 134 \\
\hline & 徒歩で避難 & 133 \\
\hline & 自動車で避難 & 303 \\
\hline & 自転車で避難 & 16 \\
\hline & 小計 & 585 \\
\hline \multicolumn{2}{|c|}{ 牡鹿半島等リアス部 } & 108 \\
\hline \multicolumn{2}{|c|}{ 移動距離不明のケース } & 104 \\
\hline \multicolumn{2}{|c|}{ 合計 } & 797 \\
\hline
\end{tabular}

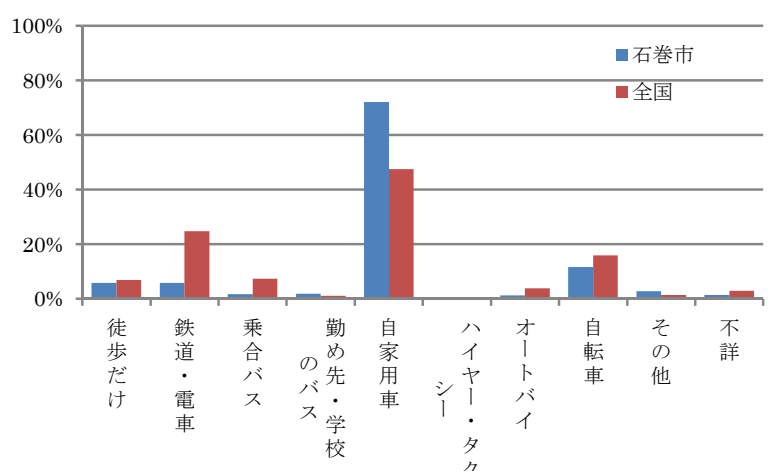

図-3 15 歳以上の常住者の通勤・通学交通手段 (2010 年国勢調査 ${ }^{5)}$ をもとにグラフ化)

表-2 に移動手段別の移動距離を示寸. 徒歩避難の平均 移動距離は約 $500 \mathrm{~m}$ である. 石巻市本庁地区での避難場 所（学校等指定の避難所や日和山，牧山などの高台）が どの住居・建物からも，おおむね $1 \mathrm{~km}$ 以内にはあること と整合的である. 自動車の平均移動距離は約 $2300 \mathrm{~m}$ であ る. 自動車の最小移動距離 $10 \mathrm{~m}$ は, アンケート回答に「家 を出て $10 \mathrm{~m}$ ぐらい走ったところで車ごと津波に流された」 との記述があったことによる. 自転車移動の件数は 16 件と少ないが平均移動距離が $2000 \mathrm{~m}$ 足らずと自動車の移 動距離と同程度となっている.

図-4 は全ケースの移動距離と累積件数割合との相関 を示したものである. 
表-2 移動手段別最大，最小，平均移動距離

\begin{tabular}{|c|c|c|c|}
\hline 手段 & 平圴移動距離 $(m)$ & 最大移動距離 $(m)$ & 最小移動距離 $(m)$ \\
\hline 徒歩 & 474 & 2100 & 20 \\
\hline 自動車 & 2285 & 14000 & 10 \\
\hdashline 自転車 & 1923 & 4400 & 80 \\
\hline
\end{tabular}

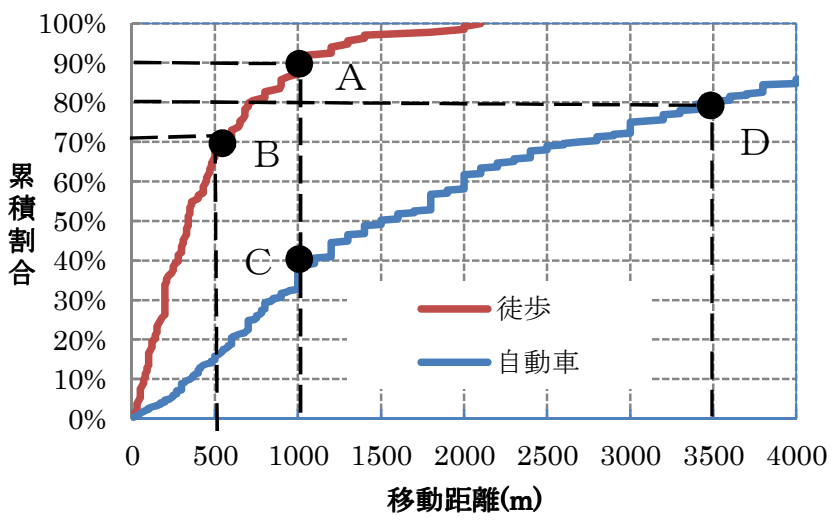

図-4 移動距離と累積割合

徒歩は 1000m 以内の移動が約 90\% (図中点A)，500m 以内の移動（点B）が約 70\%を占める. 近くの避難所や 高台に移動したケースが多いことがわかる.

これに対し自動車で避難したケースは徒歩避難と比べ 長距離移動とはなっているが，1000m以下（点C）のケ 一スが $40 \%$ を占め, 短距離を移動したケースも相当数あ ることがわかる．自動車を運転して比較的近傍の避難所
に移動したケースが多かったことがわかる.

別途実施した被災住民からの直接ヒアリングにおいて も避難所となっている学校のグラウンドが駐車した自動 車で満杯となり，出入り口付近の交通が滞留した結果， 周辺道路の渋滞を招来したとの証言もあり，避難計画に おける移動手段の適切な設定が重要な課題であることが わかる。

さらに自動車による移動では $1000 \mathrm{~m}$ から $3500 \mathrm{~m}$ までの 移動件数が全体の $40 \%$ を占める (図中点D一点C). 自 動車避難であってもはるか遠方まで移動したケースは少 なく，近くの避難所や高台に移動したケースが多いこと を示している.

\section{3. 避難者の出発地域と到達地域}

石巻市本庁地区は図-5 に示すように海岸沿い東西 10 数 $\mathrm{km}$ にわたって広がっており, 職域・住域が分散してい る. 海岸線から離れる南北方向をみると, ほぼどの地点 からも $1 \mathrm{~km}$ 以内には避難場所（避難所，高台）が存在す る. 地震発生が 15:00 近くであり住民の避難開始は自宅 からと職場など外出先からに分かれる.

今回の地震において, 津波が到達するまでの数 10 分間 での避難行動の出発点と到達点および移動手段, 移動距 離を検証することは，多様な条件を考慮する防災避難計 画の立案などに有用なものである.

ここでは石巻市本庁地区を図-5 に示す 9 地域に分割 し, 585 回答の出発地域と到達地域の内訳を表-3. 1 3. 3 に全体数と移動手段別 (徒歩, 自動車) にまとめた.

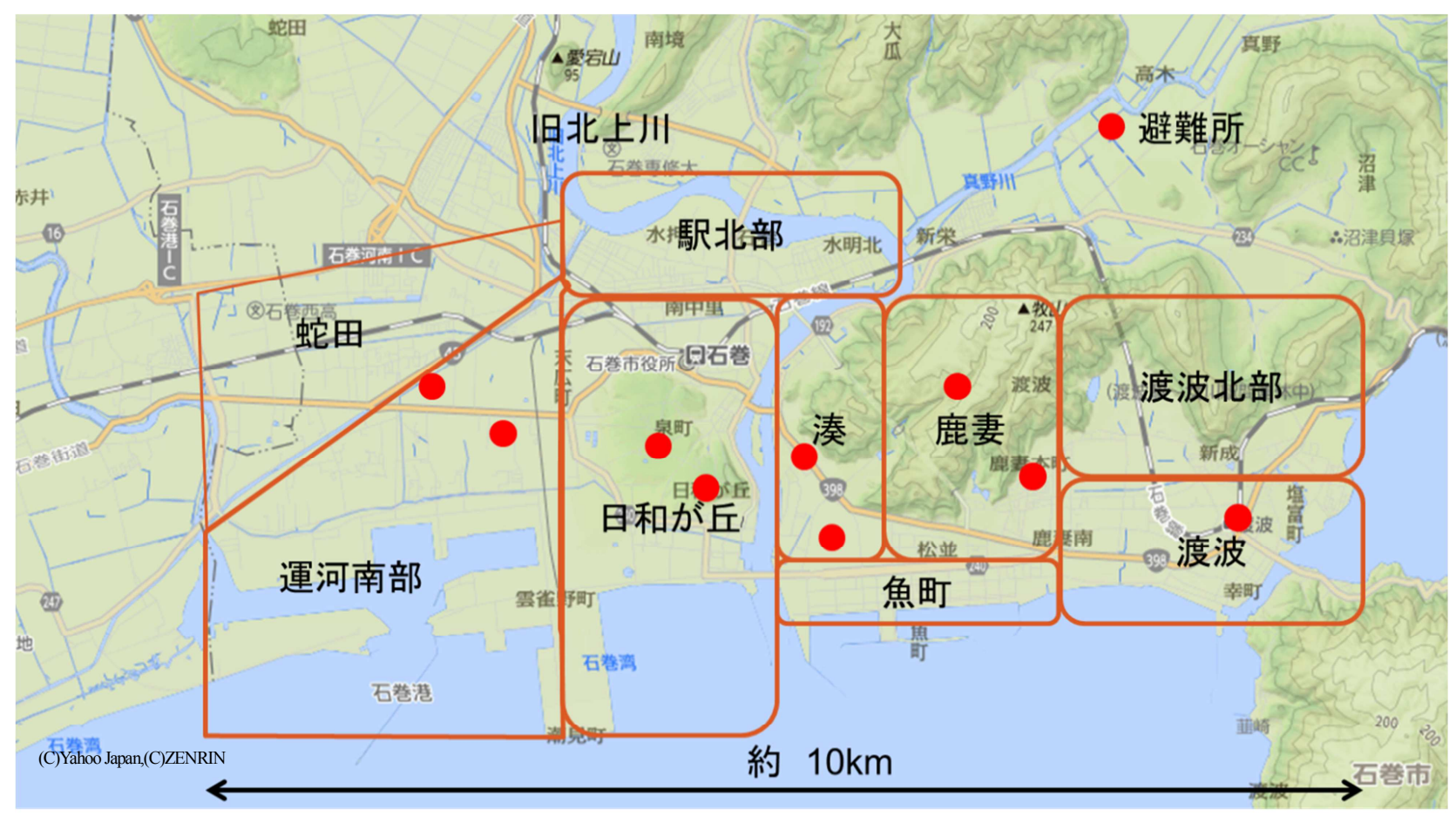

図-5 石巻本庁地区と地域分割 
地域分割においては次の事項に留意した.

(1) 各生活圈となっている地域において主に避難所と なった所を主体として地域を分割する（渡波地区： 渡波小学校, 湊地区 : 湊小学校, 牧山, 日和地区 : 門脇小，日和山など).

(2) 渋滞した国道 398 号など石巻本庁地区を東西に横 断する自動車移動の概要を基礎データとして把握 する. 特に旧北上川を横断するケースという観点か ら整理する.

(3) 高台として地域住民に認識されている日和山, 牧山 への移動概要を把握する.

(4) 地域の特徵的な職域である魚町からの出入りを把 握する.

全体的にみると「渡波地域から渡波地域」「湊地域か ら湊地域」など同一地域内の移動が多いことがわかる(表 -3.1). これは徒歩避難で顕著である（表-3.2）。自動車 避難の場合 (表-3.3) も同じ傾向であるが高台のある「日 和が丘地域」に「駅北部地域」や「運河南地域」から避 難したケースもかなり多いことがわかる.

旧北上川より東の区域で（渡波，鹿妻，湊）は同一地 域内の避難が多く，西の区域（日和が丘，駅北部，運河 南, 蛇田）では同一地域内と日和が丘への避難が多いこ とがわかる。

旧北上川の東西で避難傾向がやや異なることから，表 -3.1〜3.3 の分類結果をもとに避難パターンとして「地 域内の移動」,「隣接地域への移動」,「河川を横断しての 移動」,「本庁地区外への移動」の 4 パターンに分類した. それぞれは表-3.1３.3 に示す表の背景色で区分してい る.

図-6 は全数, 徒歩移動, 自動車移動それぞれについて 上記 4 パターンの割合を示したものである.

全回答 (左図) のうち 67\%が地域内移動となっている. 隣接地域移動も $23 \%$ あ両者併せて $90 \%$ となる. 旧北上 川を挟んで東西それぞれの地域内で移動したケースが 90\%となっている. 河川を横断しての移動は全体の 5\%で ある.

徒歩移動（中央図）では地域内移動が $87 \%$ 占め，河
表-3.1 出発地域, 到達地域別件数（全体件数）

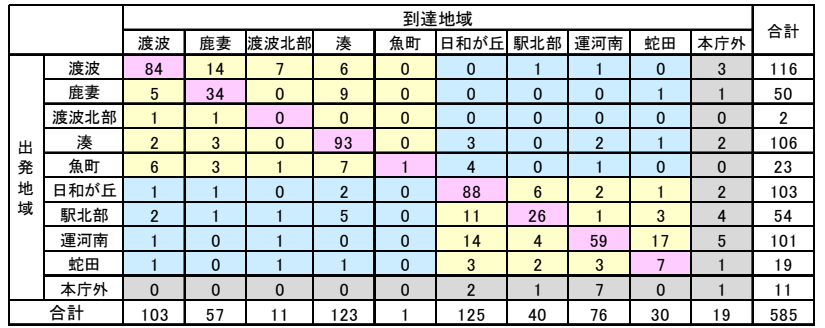

表-3.2 出発地域, 到達地域別件数（徒歩避難）

\begin{tabular}{|c|c|c|c|c|c|c|c|c|c|c|c|c|}
\hline & \multicolumn{10}{|c|}{ 到達地域 } & \multirow{2}{*}{ 合計 } \\
\hline & & 渡波 & 鹿妻 & 渡波北部 & 湊 & 魚町 & 日和が丘 & \begin{tabular}{|l|} 
駅北部 \\
\end{tabular} & 運河南 & 蛇田 & 本庁外 & \\
\hline \multirow{11}{*}{$\begin{array}{l}\text { 出 } \\
\text { 發 } \\
\text { 域 }\end{array}$} & 渡波 & 14 & 7 & 0 & 0 & 0 & 0 & 0 & 0 & 0 & 0 & 21 \\
\hline & 鹿妻 & 0 & 6 & 0 & 3 & 0 & 0 & 0 & 0 & 0 & 0 & 9 \\
\hline & 渡波北部 & 0 & 1 & 0 & 0 & 0 & 0 & 0 & 0 & 0 & 0 & 1 \\
\hline & 湊 & 1 & 0 & 0 & 35 & 0 & 0 & 0 & 0 & 0 & 0 & 36 \\
\hline & 魚町 & 0 & 1 & 0 & 0 & 0 & 0 & 0 & 0 & 0 & 0 & 1 \\
\hline & 日和が乒 & 0 & 0 & 0 & 0 & 0 & 35 & 1 & 0 & 0 & 0 & 36 \\
\hline & 駅北部 & 0 & 0 & 0 & 0 & 0 & 1 & 9 & 0 & 0 & 0 & 10 \\
\hline & 運河南 & 0 & 0 & 0 & 0 & 0 & 0 & 1 & 14 & 1 & 0 & 16 \\
\hline & 蛇田 & 0 & 0 & 0 & 0 & 0 & 0 & 0 & 0 & 3 & 0 & 3 \\
\hline & 本庁外 & 0 & 0 & 0 & 0 & 0 & 0 & 0 & 0 & 0 & 0 & 0 \\
\hline & 合計 & 15 & 15 & 0 & 38 & 0 & 36 & 11 & 14 & 4 & 0 & 133 \\
\hline
\end{tabular}

表-3.3 出発地域, 到達地域別件数（自動車避難）

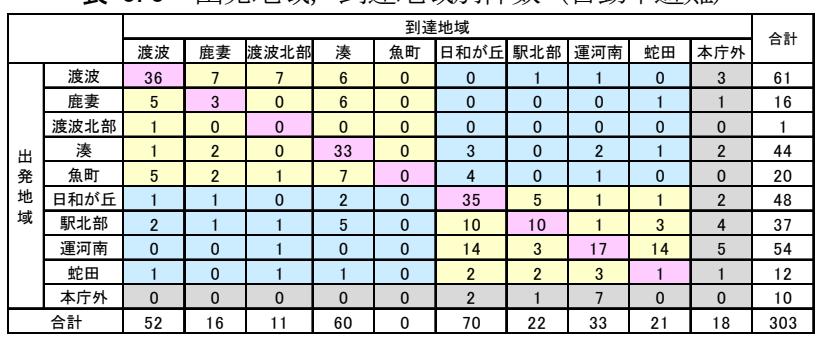

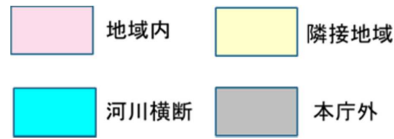

表の背景色
本庁外

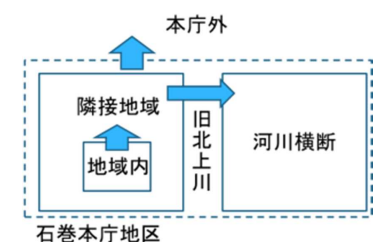

石巻本庁地区
川横断や本庁外移動は $0 \%$ あるあ. 自動車避難 (右図) で は地域内移動が $45 \%$, 徒歩移動と比較すると隣接地域移 動が 36\% と増加している. これは自動車を活用して隣接 区域の高台へ移動したケースが多かったことを示してい る. 旧北上川より東側地域では牧山，西側地域では日和 山へ避難している．徒歩移動では近傍の避難所へ，自動 車移動では近傍の避難所とやや遠くても高台に行くケー スがあることを示している. 自動車避難の方が避難場所

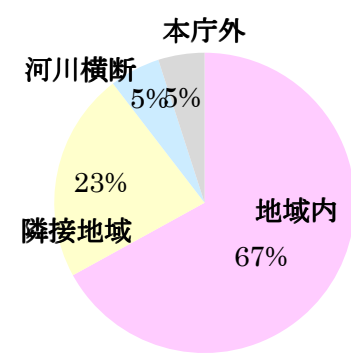

全体 585 件
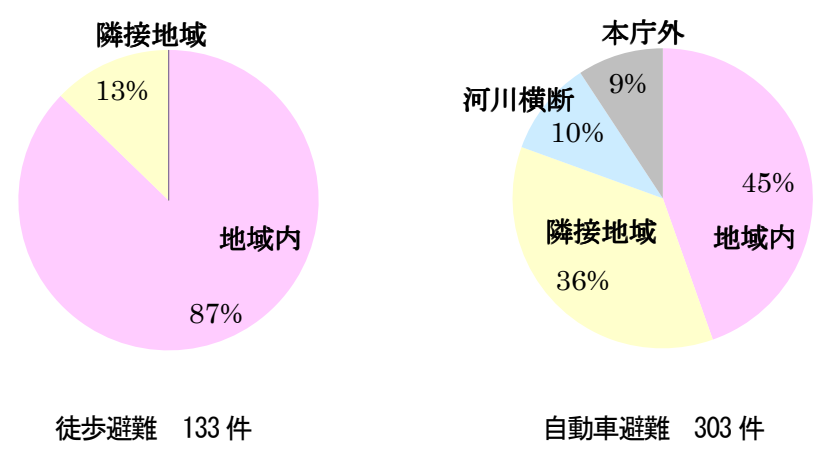

自動車避難 303 件

図-6 避難パターン別移動件数 
の選択肢が多様になることを示している.

自動車避難の $10 \%$ は河川を横断しての移動となって いる. 旧北上川を横断して石巻市本庁地区の東西を連絡 する橋梁は南側から「日和大橋」,「内海橋」,「石巻大橋」 の 3 本に限定され, 地震時の急激な交通量の増加は国道 渋滞の要因と考えられ正確な車両発生台数の特定に基づ く検証が必要である.

図-7 は自動車避難における避難パターンごとの件数 とそれぞれの平均移動距離を示したものである. 最も件 数の多い地域内移動の平均移動距離は約 $1000 \mathrm{~m}$ である. 自動車を使用しなくても十分安全な時間内に避難できる ケースもかなり多かったことを示している. 図-8 は避難 パターンごとの「誰と避難したか」の設問 (多項目選択) に対する回答割合を示したものである.地域内移動をみ ると，自分ひとりで避難したケースは 7\%にすぎず家族と いっしょに逃げたケースが $72 \%$ と大半を占める. 図-9 は 同様の条件における年齢構成を示したものである. 地域 内移動をみると， 60 歳以上がほぼ半数を占める.

前述（図-3）の平常時における自動車利用率の高いこ とに加え避難者が高齢で家族による一体的移動をせざる を得ないことが地域内の比較的短距離の移動においても 自動車が多く使用されたことの大きな要因となっている と考えられる.

運河横断の場合は平均移動距離が 4000m 以上となって おり，その中には職場など外出先から自宅に向から車も 多く含まれる.

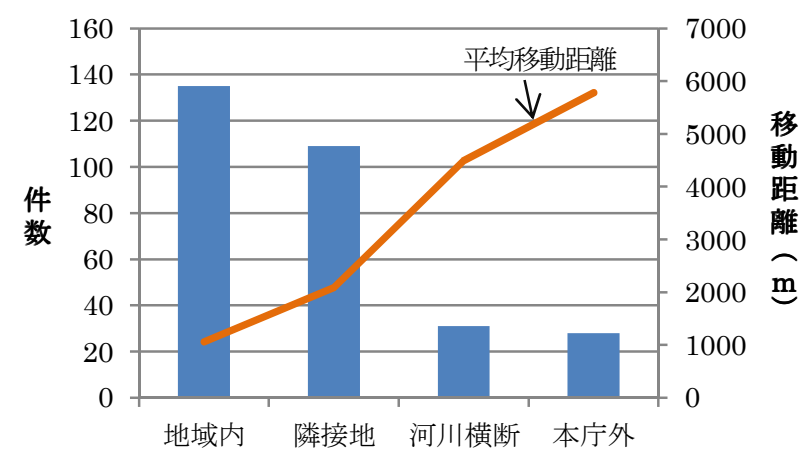

図-7 避難パターン別移動件数と平均移動距離（自動車避難）

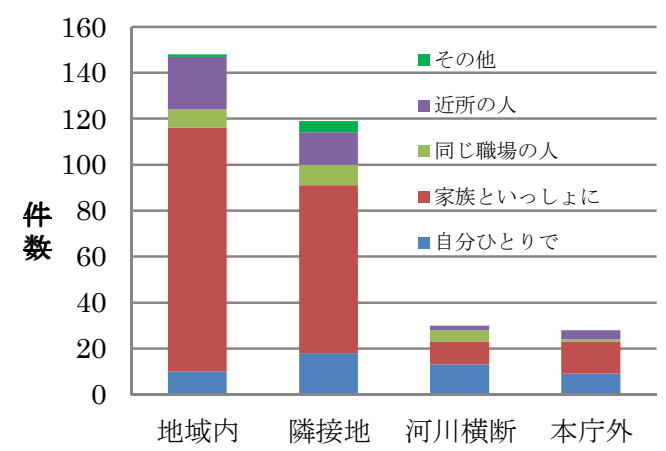

図-8 避難パターン別移動における同行者内訳（自動車避難）

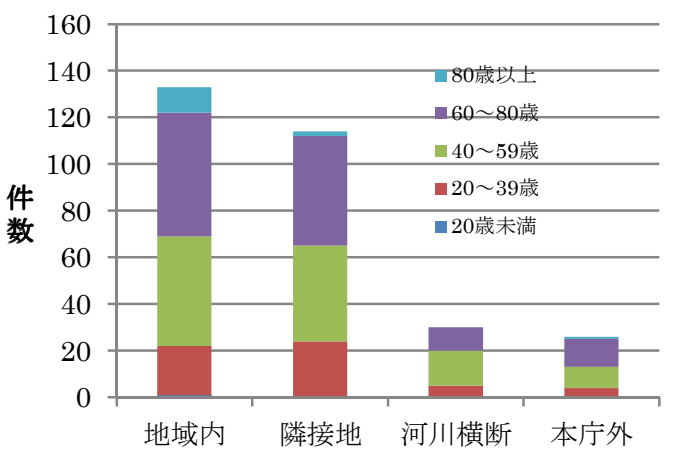

図-9＼cjkstart避難パターン別移動における年齢内訳(自動車避難)

\section{4. 外出先から自宅を経由する避難}

被災住民からの直接ヒアリングによると，職場や外出 先から家族の安否確認などを目的に自宅に一旦戻ってか ら避難場所に移動したケースがかなり多かった．自宅に 戻ってから津波に巻き込まれた事例もあり，自宅を経由 することに避難時間を要したことが避難行動の成否に大 きな影響を及ぼしたと考えられる.

図-10 は徒歩避難, 自動車避難について「自宅から直 接避難場所へ移動したケース」,「外出先から自宅に戻っ てから避難場所へ移動したケース」，「外出先から直接避 難場所へ移動したケース」の件数を示したものである.

徒歩避難では外出先から自宅に戻ったケースは全 133 件中わずか 5 件である.これに対し自動車避難では外出 先から自宅に戻ったケースは全 303 件中 78 件（25\%） と なっている．自宅に戻ったのは殆どが自動車避難である ことがわかる.

外出先から自宅を経由せず直接避難場所に移動したケ 一スは徒歩避難，自動車避難共にそれぞれの全件数の約 20\%となっている.

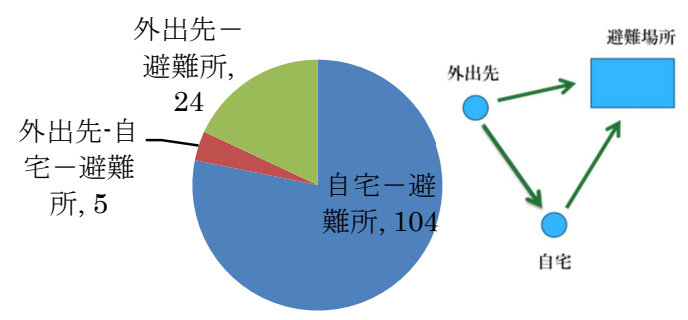

徒歩避難

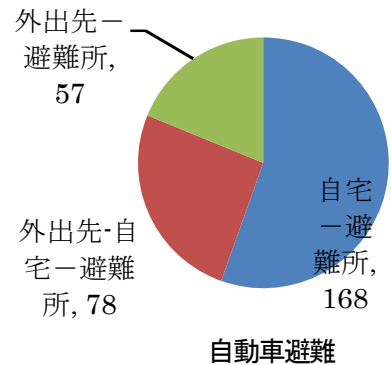

図-10 避難経路別件数 
自動車避難について移動経路別に移動距離で整理した ものを図-11 に示す. 自宅から直接避難場所へ移動した ケースは $2000 \mathrm{~m}$ 以内の移動距離が多く，特に $1000 \mathrm{~m}$ 以内 の移動は 80 数件（約 55\%) となっている. 外出先から自 宅を経由するケースでは $1000 \mathrm{~m}$ 以内が 16 件 (約 20\%) で あるのに対し，3000m 以上の移動が 35 件（約 45\%）と自 宅経由移動全件数のほぼ半分となっている.

自宅を経由したケースを対象に移動距離別に外出先か ら自宅まで (以後 : 州路) および自宅から避難場所まで （以後 : 避難路）の平均距離を計算したものが図-12 で ある。全平均值も併記している。全平均では帰路が約 $2500 \mathrm{~m}$, 避難路が約 $800 \mathrm{~m}$ となっており帰路は全避難路の $75 \%$ を占めている. 自宅経由避難の約 $45 \%$ を占める $3000 \mathrm{~m}$ 以上の移動においてもほぼ同様の割合となってい る. 自宅を経由する場合, 外出先から自宅へ戻る距離の 割合がかなり大きいことがわかる.

図-13 は各回答者が避難拠点間に要した時間の記述 （図-1）から，避難開始時間，帰路における実家・親戚 宅へ等への立寄り時間，帰路における実走行時間，自宅 での帯在時間，避難路における実家・親戚宅へ等への立 寄り時間，避難路における実走行時間を抽出し，それぞ れの平均值を移動距離別に示したものである. 全平均值 をみると全避難行程で 36.4 分を要し, 帰路走行に 14.5 分, 避難路走行に 6.3 分を要している. $3000 \mathrm{~m}$ 以上の移 動では全避難行程に 39.8 分を要しており, 石巻市におけ る津波到達時間約 40 分（津波最大波到達時刻 15:26 $6^{3)}$ ) とほぼ一致している.

帰路走行時間，避難路走行時間をみると移動距離にか かわらず帰路の割合が大きくなっており図-12 の移動距 離の割合と整合的である.

$1000 \mathrm{~m}$ 未満移動では自宅滞在時間, 帰路立寄時間が他 の移動距離範囲より長くなっており移動距離が短いにも かかわらず全避難行程に要する時間が長くなる要因とな つている. 立寄時間の記述内容は声掛け、安否確認を目 的とした実家・親戚宅への滞在のほかに避難所と自宅を 往復したり複数の避難場所に行った時の途中の避難所で の帯在時間も含まれ, 避難者は移動距離 (避難路) が短い と最初の避難所にとどまらず多様な移動パターンをとる ことを反映していると考えられる.

外出先から自宅を経由したケース全体で地震発生から 避難開始までに要した時間は 7.9 分である. 帰路の平均 走行時間が 14.5 分なので，津波到達までの時間を 40 分 とすると，自宅に戻ってから直ぐに避難所に向かったと しても避難可能時間は 17.6 分しかなかったことになる. 避難合計距離が $3000 \mathrm{~m}$ 以上になるとさらに帰路に要する 時間が増加しているので避難可能時間が 14.6 分 $(40-18.2-7.2=14.6)$ となる.

なお，徒歩避難の場合は外出先から自宅を経由したケ
一スは 5 件と少ないが，避難開始までに 5 分，帰路の平 均值が 13 分となっており避難可能時間は 22 分となって いる. 帰路に要する走行時間が避難持ち時間をかなり減 少させたことは自動車避難と同様である.

これらの結果は別途実施したヒアリング調査において 自宅に戻って間もなく津波にのまれたとの事例がいくつ かあったことと整合的である。

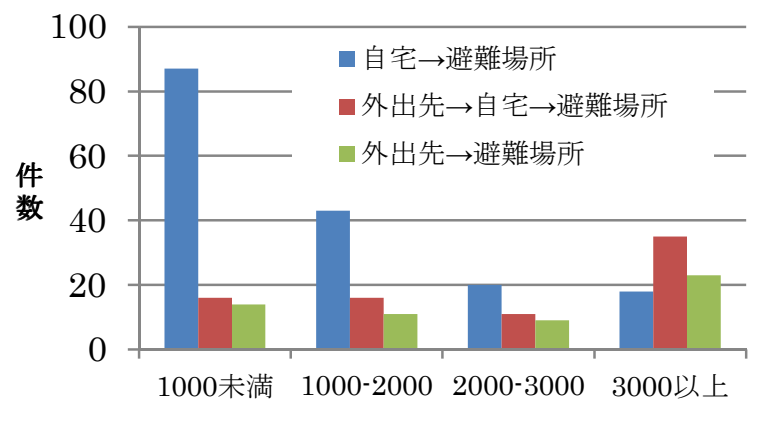

移動距離の範囲 $(\mathrm{m})$

図-11 移動距離別避難経路件数（自動車避難)

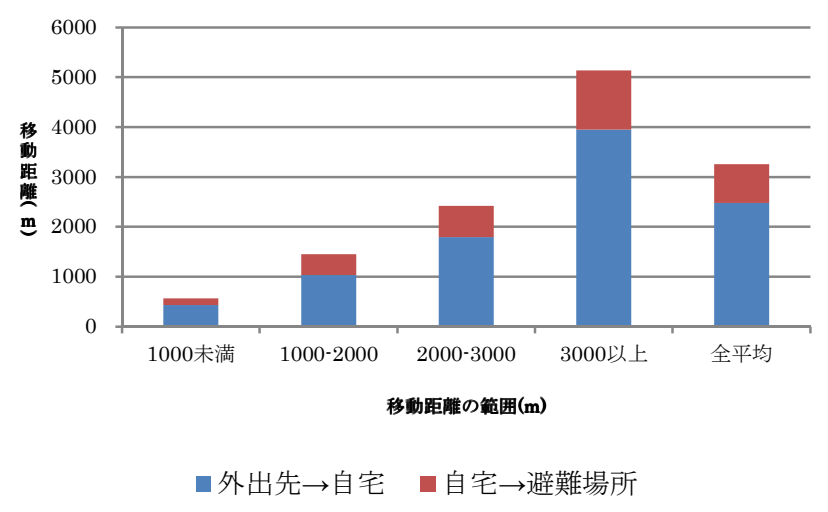

図-12 自宅経由避難者の移動距離内訳（自動車避難）

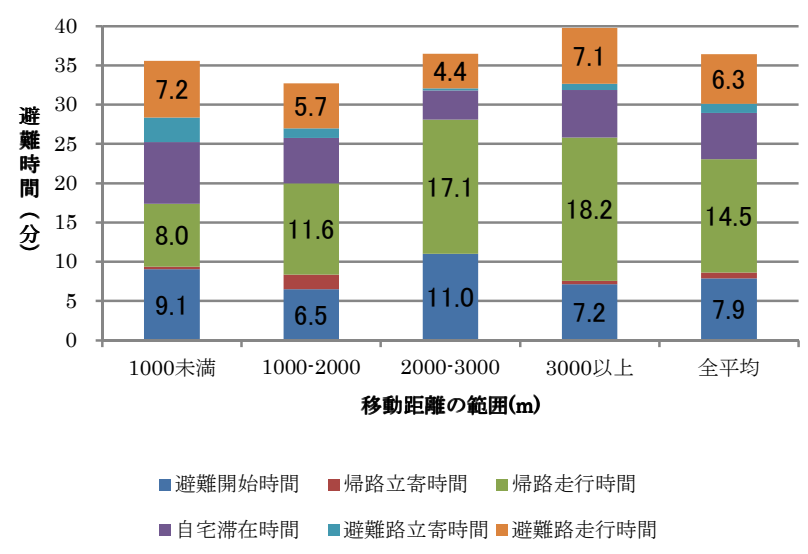

図-13 自宅経由避難者の移動時間内訳（自動車避難） 


\section{5. 渋滞に巻き込まれた自動車の割合}

自動車で移動したケースで「渋滞に巻き込まれた」と 回答した件数を移動距離別に整理したものを図-14 に示 す（自動車で避難した全 303 件で溙滞に巻き込まれたケ 一スは 115 件 (38\%) である). 渋滞に巻き込まれた割合 は移動距離の長短に関わらず 30〜 50\%である. 県警聞き 取り状況調査 ${ }^{6)}$ によると, 市内を東西に横断する国道 398 号が全面的に渋滞していたとの目撃証言が得られており, 広範囲にわたる渋滞が発生していたことが反映されてい ると考えられる.

村上・他 ${ }^{7)}$ は, 石巻市の同じアンケート結果をもとに, 移動手段と身の危険の関係を分析した．避難開始時間と 渋滞の関係では，避難が遅れるほど渋滞に巻き込まれた 割合が増し, 特に地震から 40 分以降にその危険が高くな ったことが示されている. なお, 地震から 20 分以降の避 難開始で，「渋滞で動けない車を見た」や，「車で津波に 流された」の割合が増したこともわかる.

渋滞に巻き込まれた件数を避難経路別に整理したもの を図-15 に示す. 外出先から自宅を経由して避難場所に 移動したケースは 28\%（全 78 件中 22 件）と外出先から 避難場所に直接移動したケース $(47 \%)$ と比較し少なく なっている. 表-1の記述内容から, 外出先から自宅を経 由したケースでは「渋滞をみたので裹道を通って自宅に 戻った」との記述が数例あった. 外出先から直接避難所 へ行ったケースでは「自宅に帰ろうとしたが渋滞に遭遇 し，避難所へ行った」との記述があり，啮滞への対処方 法の違いが避難経路に反映していると考えられる.

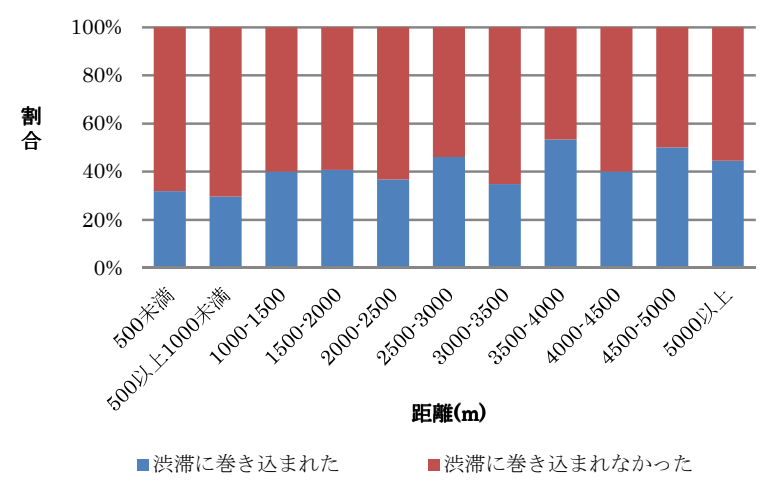

図-14 距離別啮滞遭遇率

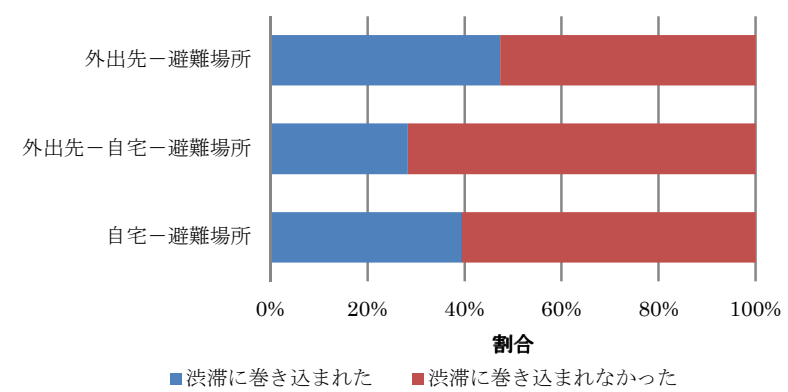

図-15 経路別渋滞遭遇率

\section{6. まとめ}

石巻本庁地区のポスティングアンケート結果から次の ことが明らかとなった。

(1) 移動手段では自動車避難が半数を占める.

(2) 平均移動距離は徒歩が $474 \mathrm{~m}$, 自動車が $2285 \mathrm{~m}$, 自 転車が 1923m である.

(3)徒歩による移動距離は $90 \%$ が 1000m 以下であり, 自 動車による避難は 40\%が 1000m 以下である.

(4) 全避難ケースのうち地域内, 隣接地域内への移動が 90\%を占める. 地域内移動でも自動車避難が多く, 平均移動距離約 $1000 \mathrm{~m}$ であり徒歩でも避難できた ケースが多い.

(5)上記は平常時における自動車利用率の高いことに 加え避難者が高齢で家族による一体的移動をせざ るを得ないことが要因となっている.

６）自動車避難の $10 \%$ は運河を横断しての移動である.

(7)自動車による避難では外出先から自宅を経由し避 難場所へ移動したケースが $25 \%$ 占める.またこの ケースでは移動距離 $3000 \mathrm{~m}$ 以上が 45\%を占める.

(8) 自動車で自宅を経由することによる自動車走行に よる時間ロスは平均的に約 15 分である.

(9)渋滞に巻き込まれた自動車は自動車避難の $38 \%$ を 占める.

(10)自動車避難で自宅を経由した場合平均的にみると 避難開始時間 (8 分) +自宅経由の時間ロス (15 分) $=23$ 分となり石巻市本庁地区における避難可能時 間 40 分に対し 17 分しか余裕がなかった.

今後の課題は次のとおりである.

(1) 自動車避難が半数を占め近隣地域を中心とする主 要道路の渋滞発生を招来したと考えられる．特に $1000 \mathrm{~m}$ 以内の短距離移動が多く自動車を使用せずと も避難できたとの観点から, 徒歩避難を原則とする ことが重要な課題である. しかし自動車使用が多か ったことには平常時の自動車使用率の高さや避難 者の高齢化が背景としてあり地域ブロック毎の計 画的な自動車避難方法の確立も重要な課題である.

(2) 自動車避難者の $1 / 4$ は自宅に戻っており, 渋帯の要 因となると共に避難者本人の避難可能時間を著し く短くすることとなった．居住域・職域，家族構成 など日常の生活パターンに配慮した避難計画の立 案が重要である.

(3) 自動車避難の 90\%は近隣への移動であるが河川を横 断しての移動も $10 \%$ 占める. 地震後の自動車走行 発生台数を正確に把握し, 河川を渡って市街地を東 西に横断する道路を中心とする渋滞状況をシミュ 
レートすることが今後の防災計画の立案等に有効 である.

謝辞 : 本調査にご協力いただいた石巻市の皆様と石巻市 役所の皆様に深く感謝いたします.この調査は科学技術 振興機構の「国際緊急共同研究・調査支援プログラム (J-RAPID)」，土木学会の支援を受けた東日本大震災津波 避難合同調査団 (石巻市担当チーム)の調査結果を用いて 取りまとめたものである.

\section{参考文献}

1) 後藤洋三，中林一樹 : 東日本大震災津波避難合同調査団 （山田・石巻市担当チーム）の調査，土木学会第 67 回年 次学術講演会, 2012 .

2) 後藤洋三 : 被災地からの声, 日本地震工学会論文集・特 集号「2011 年東日本大震災」, 2012.

3）国土交通省 : 津波避難を想定した避難路，避難施設の配 置及び避難誘導について (改訂版), 2012.
4) 柳原純夫，村上ひとみ : 石巻市本庁地区における避難行 動の移動距離からの分析, 土木学会第 67 回年次学術講演 会, 2012 .

5) 平成 22 年国勢調査 従業地・通学地による人口・産業等 集計 04 宮城県

http://wwwe-stat.jp/SGL/estat/List.do?bid=000001039657\&cyc ode $=0 \quad$ (2013.1.14 閲覽 $)$

6) 中央防災会議 東北地方太平洋沖地震を教訓とした地 震・津波対策に関する専門調査会（第9回） 2011 資料 1 警察庁提供資料

http://www.bousai.go.jp/jishin/chubou/higashinihon/9/1.pdf (2012.8.5 閲覧)

7) 村上ひとみ, 三上卓, 柳原純夫 : 東日本大震災における 津波避難の交通手段と危険度-石巻市のアンケート調査 をもとに-第 32 回地震工学研究発表会講演論文集, 論文 ID 6-377, 2012.

(2012. 11. 16 受付, 2013.1.31 修正, 2013.2. 23 受理)

\section{A STUDY ON TRAVEL MEANS AND DISTANCES OF TSUNAMI EVACUATION IN ISHINOMAKI URBAN AREA AFTER THE 2011 GREAT EAST JAPAN EARTHQUAKE DISASTER}

\section{Sumio YANAGIHARA and Hitomi MURAKAMI}

The travel distances and means of transport for tsunami evacuation in urban area of Ishinomaki city were investigated. The survey data was based on responses of 797 cases for questionnaire about the evacuation from the tsunami in the great east Japan earthquake disaster. The questionnaires were collected from people living in the temporary houses in Ishinomaki city. Following findings were obtained. 1) Half of respondents evacuated by cars. 2) $90 \%$ of respondents who evacuated on foot moved to places within $1 \mathrm{~km}$ distance. 2) $40 \%$ of respondents who evacuated by cars moved less than $1 \mathrm{~km}$. 3) A quarter of respondents who evacuated by cars came back to their homes once and they had only 17 minutes in average left to evacuate. 4) Two fifths of respondents who evacuated by cars were in traffic jams. 